\title{
Animal Nutrition
}

by ARON A. BONDI, Emeritus Professor of Animal Nutrition and Biochemistry, Hebrew University of Jerusalem

A comparative study of the basic biochemical and physiological basis of nutrition in farm animals, with an emphasis on applying new research data to the design of feeding regimes which will result in the most efficient use of feedstuffs for different productive purposes. Professor Bondi clearly outlines the major metabolic pathways in a range of animals, highlighting how individual nutrients are digested and absorbed and how these processes provide the animal with energy and lead to the formation of animal tissues in the form of meat or other products such as milk and eggs.

This insight into the basic biological processes underlying nutrition will be of value to students and researchers of animal and veterinary science, feedstuff producers and progressive farmers as well as basic biochemists and nutritionists.

$0477903752 \quad 588 p$ January $1987 \quad \mathbf{f 4 5 . 0 0 / \$ 7 6 . 7 3}$

\section{Agriculture}

Foundations, Principles \& Development

\section{J.R. RAEBURN}

" ... The special advantage of this book is not only of theoretical deepness and thoroughness but also the explanation of analyses and the concepts discussed with numerous relevant examples taken from different sites in the world ... recommended." JOURNAL OF AGRONOMY \& CROP SCIENCE

047110308X 344pp September $1984 \quad £ 15.95 / \$ 28.10$

Telephone your credit card order: (0243) 829121 Customer Service Dept.

Freefone - Dial 100 and ask for Freefone 3477 (UK only)

We will refund your payment without question if you return any unwanted title to us in re-saleable condition within 30 days.

All books also available from your bookseller

\section{John Wiley \& Sons Ltd}

Baffins Lane, Chichester, Sussex PO19 1UD, England

\section{(1): John Wiley \& Sons (15:)}




\section{THE JOURNAL OF \\ AGRICULTURAL SCIENCE}

EDITED BY

R. B. AUSTIN, D.SC., Plant Breeding Institute, Cambridge

B. W. BACHE, M.A., PH.D., C.CHEM., F.R.S.C., Department of Applied Biology, Cambridge

Prof. Sir J. W. L. BEAMENT, sC.D., F.R.S., Department of Applied Biology, Cambridge

G. D. H. BELL, C.B.E., PH.D., SC.D.(h.c.), D.SC.(h.c.), F.R.S., 6 Worts Causeway, Cambridge

Sir K. L. BLAXTER, PH.D., N.D.A. (HONS.), D.SC., F.R.S.E., F.R.S., Stradbroke Hall,

Stradbroke, Suffolk

Prof. A. D. CARE, D.sC., M.R.C.v.S., Department of Animal Physiology and Nutrition, Leeds

J. A. CURRIE, PH.D., 6 Falconers Field, Harpenden

W. DA Y, PH.D., Rothamsted Experimental Station, Harpenden

S. K. ELTRINGHAM, PH.D., Department of Applied Biology, Cambridge

Prof. J. L. JINKS, C.B.E., D.SC., F.I.BIOL., F.R.S., Agricultural and Food Research Council, 160 Great Portland Street, London W1N 6DT

D. B. LINDSA Y, B.SC., M.A., D.PHIL., CSIRO Division of Tropical Animal Science,

Tropical Cattle Research Centre, Rockhampton, Queensland, Australia

Prof. G. M. O. MALÓIY, E.B.s., PH.D., DISC., D.SC.(h.c.), F.I.BIOL., College of Agriculture and Veterinary Sciences, University of Nairobi, Kenya

Prof. J. B. OWEN, B.SC., PH.D., M.A., Department of Agriculture, Bangor

W. J. RIDGMAN, M.A., Department of Applied Biology, Cambridge

D. E. WALTERS, B.SC., PH.D., F.I.S., Cambridge Research Station (IAPGR), Babraharn Hall, Cambridge

F. YATES, C.B.E., SC.D., F.R.S., Rothamsted Experimental Station, Harpenden

Miss C. H. NORTHEAST, M.A. (Executive Editor), Department of Applied Biology, Cambridge

\section{CAMBRIDGE UNIVERSITY PRESS}

Cambridge

New York New Rochelle Melbourne Sydney

1987 


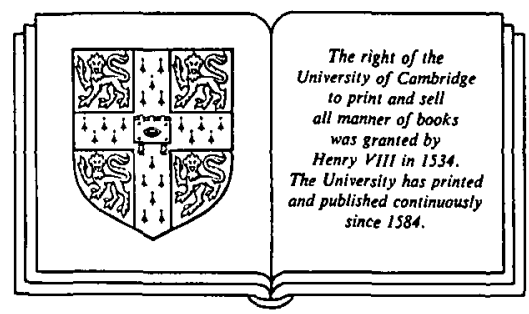

PUBLISHED BY

THE PRESS SYNDICATE OF THE UNIVERSITY OF CAMBRIDGE

The Pitt Building, Trumpington Street, Cambridge CB2 1RP

32 East 57th Street, New York, NY 10022, USA

10 Stamford Road, Oakleigh, Melbourne 3166, Australia

(C) Cambridge University Press 1987

Printed in Great Britain by the University Press, Cambridge 


\section{Contents}

\section{Part 1 (February 1987)}

PAGE

Freddenberger, D. O., Familton, A. S. and Sykes, A. R. Comparative aspects of copper metabolism in silage-fed sheep and deer (Cervus elaphus)

Gill, Margaret, Beever, D. E., Buttery, P. J., England, P., Gibi, M. J. and Baker, R. D. The effect of oestradiol-17 $\beta$ implantation on the response in voluntary intake, live-weight gain and body composition, to fishmeal supplementation of silage offered to growing calves

CASTLE, M. E. and Reid, D. A. A comparison of the effects of liquid manure (urine and water) and nitrogen fertilizers applied to a grass-clover sward on soils of different $\mathrm{pH}$ value.

RAI, R. Chemotaxis of salt-tolerant and sensitive Rhizobium strains to root exudates of lentil (Lens culinaris $\mathbf{L}$.) genotypes and symbiotic $\mathbf{N}$-fixation, proline content and grain yield in saline calcareous soil.

Fortin, A., Wood, J. D. and Whelehan, O. P. Breed and sex effects on the development and proportions of muscle, fat and bone of pigs

Homewood, Katherine, Rodgers, W. A. and Arhem, K. Ecology of pastoralism in Ngorongoro Conservation Area, Tanzania

Widdowson, F. V., Penny, A., Darby, R. J., Bird, E. and Hewitt, M. V. Amounts of $\mathrm{NO}_{3}-\mathrm{N}$ and $\mathrm{NH}_{4}-\mathrm{N}$ in soil, from autumn to spring, under winter wheat and their relationship to soil type, sowing date, previous crop and $\mathrm{N}$ uptake at Rothamsted, Woburn and Saxmundham, 1979-85

Pope, W. F., Lawyer, Michelle S. and First, N. L. Interaction of blood supply to the porcine ovary and corpora lutea function

Bond, D.A. and PoPe, M. Proportion of cross-bred and selfed seed obtained from successive generations of winter bean (Vicia faba L.) crops .

Rodgers, G. A., Penny, A., Widdowson, F. V. and Hewitt, M. V. Tests of nitrification and of urease inhibitors, when applied with either solid or aqueous urea, on grass grown on a light sandy soil

Nicholson, M. J. The effect of drinking frequency on some aspects of the productivity of zebu cattle

Ford, C. W., Elliott, R. and Maynard, P. J. The effect of chlorite delignification on digestibility of some grass forages and on intake and rumen microbial activity in sheep fed barley straw

OFUYA, T. I. Susceptibility of some cow peas to infestation and damage by the storage beetle, Callosobruchus maculatus (Fabricius) (Coleoptera: Bruchidae)

Fortin, A., Wood, J. D. and Whelehan, O. P. Breed and sex effects on the development, distribution of muscle, fat and bone, and the partition of fat in pigs

Crosbie, S. F., Smallfield, B. M., Hawker, H., Floate, M. J. S., Keoghan, J. M., Enright, P. D. and Abernethy, R. J. Exploiting the pasture capacitance probe in agricultural research: a comparison with other methods of measuring herbage mass .

Allen, E. J. and O'Brien, Susan A. An analysis of the effects of seed weight, seed rate and date of harvest on the yield and economic value of seed-potato crops .

Mukhtar, N. O. and AbU NaIb, Saypa A. Inoculation of irrigated soya bean in the Sudan Gezira

Ridgman, W. J. and Wedgwood, R. B. Some residual effects of crop rotation on light land

Lutman, P. J. W. and Dixon, Fiona L. The effect of drilling date on the growth and yield ofoil-seed rape (Brassica napus L.) 
Ford, C. W. and Ellio'st, R. Biodegradability of grass cell walls in relation to chemical composition and rumen microbial activity

amaning-Kwarteng, K. and Kellaway, R. C. Influence of cotton-seed meal and barley grain supplements on intake, digestion, live-weight gain and wool growth in sheep fed $\mathrm{NaOH}$-treated oat and wheat straw diets

Benjamin, L. R. The relative importance of cluster size, sowing depth, time of seedling emergence and between-plant spacing on variation in plant size in red beet (Beta vulgaris L.) crops

LitTLE, D. A. The influence of sodium supplementation on the voluntary intake and digestibility of low-sodium Setaria sphacelata cv. Nandi by cattle . . . .

Martens, H., Kubel, O. W., Gäbel, G. and HoniG, H. Effects of low sodium intake on magnesium metabolism of sheep .

\section{SHORT Notes}

Singh, S. and Gururaja RaO, P. N. Varietal differences in growth characteristics in sugar cane

Jefferies, R. A. and Mackerron, D. K. L. Thermal time as a non-destructive method of estimating tuber initiation in potatoes .

Alam, M. R., Poppi, D. P. and Sykes, A. R. Comparative aspects of water intake and its flow through the gastro-intestinal tract of kids and lambs .

Part 2 (APRL 1987)

Khalifa, F. M. Effect of nitrogen on nodulation and yield of soya beans under two systems of production in Sudan.

Westcott, B. A method of assessing the yield stability of crop genotypes.

Singh, M. V., Chrabra, R. and Abrol, I. P. Interactions between applications of gypsum and zinc sulphate on the yield and chemical composition of rice grown on an alkali soil

Kroll, O., Owen, J. B. and Whitaker, C. J. Grouping and complete diet composition in relation to parity and potential yield in dairy cows

White, Ethel M. Straw and grain production in spring barley cultivars .

Sharma, B. R. Effect of time and amount of first irrigation on the root distribution and fodder yield of oats

Verma, V. D. and RAM, H. H. Genetics of seed impermeability in soya bean

Dingwall, W. S., Robinson, J. J., Aitken, R. P. and Fraser, C. Studies on reproduction in prolific ewes. 9. Embryo survival, early foetal growth and within-litter variation in foetal size

Sharma, U. C. and Arora, B. R. Effect of nitrogen, phosphorus and potassium application on yield of potato tubers (Solanum tuberosum L.).

JINDAL, S. K. Studies on the gonadal and epididymal sperm reserves of Mujjafaranagri rams

Ayling, Sarah M., Bacon, E., Christian, D. G. and Goss, M. J. The growth and yield of winter wheat following 10 years of continuous ploughing, shallow-tine cultivation or direct drilling on a non-calcareous clay soil .

Ap Dewi, I., Kelso, W. I. and Johnson, D. B. A study of field drain ochre deposits. 1. Abiotic chemical precipitation

Ap Dewi, I., Johnson, D. B. and Kelso, W. I. A study of field drain ochre deposits. 2. The distribution of micro-organisms 
Díaz-Fierros, F., Villar, M. Carmen, Gil, F., Leirós, M. Carmen, Carballas, M., Carballas, Tarsy and Cabaneiro, Ana. Laboratory study of the availability of nutrients in physical fractions of cattle slurry

KaUShik, S. K. and GaUtam, R. C. Effect of nitrogen and phosphorus on the production potential of pearl millet-cow pea or green gram intercropping systems under rainfed conditions

Shepherd, K. D., Cooper, P. J. M., Allan, A. Y., Drennan, D. S. H. and Keatinge, J. D. H. Growth, water use and yield of barley in Mediterranean-type environments .

Ryder, M. L. and Adalsteinsson, S. A note on differences in coat structure between the black and white areas of piebald lambs

Edwards, Sandra A., Rogers-Lewis, D. S. and Fairbairn, C. B. The effects of pea variety and inclusion rate in the diet on the performance of finishing pigs

Chung, B. The effect of irrigation on the growth and yield components of poppies (Papaver somniferum $\mathrm{L}$.)

ADJEI-Twum, D. C. Effects of plant density and tillage on growth and grain yield of sorghum (Sorghum bicolor (L.) Moench.) under dryland conditions in a semi-arid area in Ethiopia

Burstall, Lindsay, Thomas, M. N. and Allen, E. J. The relationship between total yield, number of tubers and yield of large tubers in potato crops .

Robrins, G. B., Bushell, J. J. and Butler, K. L. Decline in plant and animal production from ageing pastures of green panic (Panicum maximum var. trichoglume) .

Huahes, G., Keatinge, J. D. H., Cooper, P. J. M. and Dee, N. F. Solar radiation interception and utilization by chickpea (Cicer arietinum L.) crops in northern Syria .

Heath, M. C. and Hebblethwaite, P. D. Precision drilling combining peas (Pisum sativum L.) of contrasting leaf types at varying densities .

Thomas, W. T. B. The use of random $F_{3}$ families for cross prediction in spring barley .

Gillison, T. C., Jenkins, P. D. and Hayes, J. D. Some factors affecting the expression of the physiological age of potato seed tubers.

DahiYa, I. S., Grewal, K. S. and DahiYa, D. J. Desodification of a salt-affected soil in plots of various sizes under two modes of water application .

Nilsson, T. Growth and chemical composition of carrots as influenced by the time of sowing and harvest .

Waddington, S. R., Osmanzai, M., Yoshida, M. and Ransom, J. K. The yield of durum wheats released in Mexico between 1960 and 1984

Aufhammer, W., Götz, Isabella and Peter, Maria. Yield performance of field beans (Vicia faba L.) in relation to interactions between inflorescences at different nodes

Kushwaha, B. L. and De, R. Studies of resource use and yield of mustard and chickpea grown in intercropping systems

\section{SHORT Notes}

Agrawal, D. K., Garg, A. K. and Nath, K. The use of water-washed neem (Azadirachta indica) seed kernel cake in the feeding of buffalo calves

Hynd, P. I. and JAmes, R. E. The effect of trenbolone acetate and trenbolone acetate plus oestradiol $-17 \beta$ on wool growth

Ravindran, V., Rajaguro, A. S. B. and De Silva, Chitra. Evaluation of rubber (Hevea brasiliensis Muell-Arg.) seed meal in White Leghorn cockerel diets

Goyal, S. P. and Ghosh, P. K. A note on the measurement of heat exchange by radiotelemetry in black desert goats during winter

Hunter, R. A., Davey, Jane B. and Buttery, P. J. Fractional rate of protein synthesis in liver and in individual muscles of lambs: effect of time of sampling following the use of the continuous infusion technique 
Thorne, Glulian N. and Wood, D. W. The fate of carbon in dying tillers of winter wheat

Dawson, Sîn E. The manurial value of sewage sludge applied to fen peat soils

Christie, P. Some long-term effects of slurry on grassland.

Snape, J. W., Angus, W. J., Parker, Beryl and Leckie, Debra. The chromosomal locations in wheat of genes conferring differential response to the wild oat herbicide, difenzoquat .

Chaiyabutr, N., Buranakarl, C., Muangcharoen, V., Loypetjra, P. and PichaicharNARONG, A. Effects of acute heat stress on changes in the rate of liquid flow from the rumen and turnover of body water of swamp buffalo .

OGunkunle, A. O. and BeCKeTt, P. H. T. Comparative influence of soil and management on barley yield in the Vale of Whitehorse, England .

Saran, G. and GirI, G. Influence of dates of sowing on Brassica species under semi-arid rainfed conditions of north-west India .

Gutperidae, R. J., Bateman, G. L. and Hornby, D. Comparison of the effects of spring applications of ammonium chloride and other nitrogen fertilizers on take-all in winter wheat

REDdy, M. D. and GHosh, B. C. Comparative efficiency of different planting methods in intermediate deepwater $(15-50 \mathrm{~cm})$ rice

Williams, Ingrid H., Martin, A. P. and Kelm, Maria. The phenology of the emergence of brassica pod midge (Dasineura brassicae Winn.) and its infestation of winter oil-seed rape (Brassica napus L.)

Leech, Anne F. and Thornton, I. Trace elements in soils and pasture herbage on farms with bovine hypocupraemia .

Hadjichristodovlou, A. The effects of optimum heading date and its stability on yield and consistency of performance of barley and durum wheat in dry areas.

Papastylianod, I. and Samios, Th. Comparisons of rotations in which barley for grain follows woollypod vetch or forage barley

Aboul-Naga, A. M., Aboul-Ela, M. B., El-Nakhla, S. M. and Mehrez, A. Z. Oestrous and ovarian activity of subtropical fat-tailed Rahmani sheep and their response to light treatment

Papastylanod, I. Effect of preceding legume or cereal on barley grain and nitrogen yield

Anwarulla, M. Syed and Shivashankar, K. Influence of seed treatment and foliar nutrition of molybdenum on green gram and black gram

Jena, P. K. and RaO, V. Rajaramamohan. Nitrogen fixation as influenced by pesticides and rice straw in paddy soils

IкнатUа, U. J., Еносне, O. W. and Uмон, J. E. The influence of feeding frequency on feed intake, nutrient utilization and nitrogen metabolism in growing zebu cattle

Kayode, G. O. Potassium requirement of groundnut (Arachis hypogeae) in the lowland tropics.

Prasad, G. S. V., Sastry, M. V. S., Srinivasan, T. E. and Kalode, M. B. Linkage between brown planthopper resistance and morphological characters is rice

Rusoke, D. G. and Fatunla, T. Inheritance of pod and seed resistance to the cow-pea seed beetle (Callosobruchus maculatus Fabr.)

Ogunwolu, E. O., REagan, T. E. and Damann, K. E. JR. Efficacy of pest control strategies in Louisiana sugar cane: a preliminary survey

Hammouda, A. M. Blossom-end rot of watermelon in the southern region of Oman (Dhofar)

NoRTh, P. F. Effect of contrasting tillage procedures on the emergence of onions in relation to measured physical properties of seed beds 
ShORT Notes

Praveen-Kumar and Aggarwal, R. K. Substitution of reduced iron by zinc in total soil nitrogen estimation by modified Olsen's method.

BennetT, I. L. and Holmes, C. R. Telemetered body temperatures in a group of cattle during gestation and lactation

BhardwaJ, H. L. and Weaver, J. B. JR. Effect of cotton genotypes on numbers of adult lady beetles (Coleoptera: Coccinelliảe)

Kothari, S. K., Singh, Virendra and Singh, Kamla. Effect of rates and methods of phosphorus application on herb and oil yields and nutrient concentr:tions in Japanese mint (Mentha arvensis L.) 
KAYODE, G. O. Potassium requirement of groundnut (Arachis hypogeae) in the lowland tropics

Prasad, G. S. V., Sastry, M. V. S., Srinivasan, T. E. and Kalode, M. B. Linkage between brown planthopper resistance and morphological characters in rice . . . . . . .

Rusoke, D. G. and FATUNLA, T. Inheritance of pod and seed resistance to the cow-pea seed beetle (Callosobruchus maculatus Fabr.)

Ogunwolu, E. O., Reagan, T. E. and Damann, K. E. JR. Efficacy of pest control strategies in Louisiana sugar cane: a preliminary survey

Hammouda, A. M. Blossom-end rot of watermelon in the southern region of Oman (Dhofar) .

NORTH, P. F. Effect of contrasting tillage procedures on the emergence of onions in relation to measured physical properties of seed beds .

SHORT NOTES

Praveen-Kumar and Aggarwal, R. K. Substitution of reduced iron by zinc in total soil nitrogen estimation by modified Olsen's method

BenNetT, I. L. and Holmes, C. R. Telemetered body temperatures in a group of cattle during gestation and lactation

BhardwaJ, H. L. and Weaver, J. B. JR. Effect of cotton genotypes on numbers of adult lady beetles (Coleoptera: Coccinellidae)

Kothari, S. K., Singh, Virendra and Singh, Kamla. Effect of rates and methods of phosphorus application on herb and oil yields and nutrient concentrations in Japanese mint (Mentha arvensis $\mathrm{L}$.) 


\section{CONTENTS}

\section{Vol. 108 Part 3 June 1987}

THORNe, GILLIAN N and Wood, D. W. The fate of carbon in dying tillers of winter wheat

DAWSON, SIÂN E. The manurial value of sewage sludge applied to fen peat soils _ . $\quad$. 523

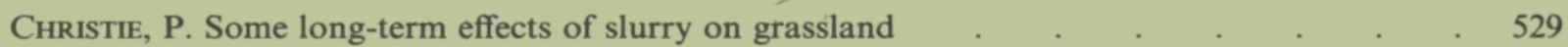

Snape, J. W., Angus, W. J., Parker, Beryl and Leckie, Debra. The chromosomal locations in wheat of genes conferring differential response to the wild oat herbicide, difenzoquat

Chaiyabutr, N., Buranakarl, C., Muangcharoen, V., Loypetjra, P. and Pichaicharnarong, A. Effects of acute heat stress on changes in the rate of liquid flow from the rumen and turnover of body water of swamp buffalo .

Ogunkunle, A. O. and Beckett, P. H. T. Comparative influence of soil and management on barley yield in the Vale of Whitehorse, England

SARAN, G. and GIRI, G. Influence of dates of sowing on Brassica species under semi-arid rainfed conditions of north-west India

Gutteridge, R. J., Bateman, G. L. and Hornby, D. Comparison of the effects of spring applications of ammonium chloride and other nitrogen fertilizers on take-all in winter wheat

Reddy, M. D. and Ghosh, B. C. Comparative efficiency of different planting methods in intermediate deepwater $(15-50 \mathrm{~cm})$ rice

Williams, Ingrid H., Martin, A. P. and Kelm, Maria. The phenology of the emergence of brassica pod midge (Dasineura brassicae Winn.) and its infestation of winter oil-seed rape (Brassica napus L.)

LeEch, Anne F. and Thornton, I. Trace elements in soils and pasture herbage on farms with bovine hypocupraemia

Hadichristodoulou, A. The effects of optimum heading date and its stability on yield and consistency of performance of barley and durum wheat in dry areas

Papastyluanou, I. and Samios, Th. Comparison of rotations in which barley for grain follows woollypod vetch or forage barley

Aboul-Naga, A. M., Aboul-Ela, M. B., El-Nakhla, S. M. and Mehrez, A. Z. Oestrous and ovarian activity of subtropical fat-tailed Rahmani sheep and their response to light treatment

Papastylianou, I. Effect of preceding legume or cereal on barley grain and nitrogen yield

Anwarulla, M. Syed and Shivashankar, K. Influence of seed treatment and foliar nutrition of molybdenum on green gram and black gram .

Jena, P. K. and RAO, V. RaJARAmamohan. Nitrogen fixation as influenced by pesticides and rice straw in paddy soils

IкнатUA, U. J., Еносне, O. W. and Uмон, J. E. The influence of feeding frequency on feed intake, nutrient utilization and nitrogen metabolism in growing zebu cattle

Continued inside back cover

(C) Cambridge University Press 1987

Copying. This journal is registered with the Copyright Clearance Center, 21 Congress Street, Salem, Mass. 01970. Organizations in the USA who are also registered with C.C.C. may therefore copy material (beyond the limits permitted by sections 107 and 108 of US copyright law) subject to payment to C.C.C. of the per-copy fee of $\$ 05.00$. This consent does not extend to multiple copying for promotional or commercial purposes. Code 0021-8596/87/108-03 \$05.00.

ISI Tear Service, 3501 Market Street, Philadelphia, Pennsylvania 19106, USA, is authorized to supply single copies of separate articles for private use only.

For all other use, permission should be sought from Cambridge or the American Branch of Cambridge University Press. 